\title{
Variation of Groundwater and Rainwater Quality in a Nigerian Leper Colony
}

\author{
Rebecca A. Olaoye, Akinwale O. Coker, and Mynepalli K. Sridhar
}

\section{ABSTRACT}

\begin{abstract}
Adequate supply of potable water is a major challenge in most leper colony with emphasis often placed on water needs of "normal" people but little concern on the safe water source for the physically challenged and vulnerable lepers with limited mobility who cannot search for other sources of water outside designated colony. This study was designed to investigate the quality of water sources within a Nigerian leper colony. Periodic characterization of groundwater and rainwater samples was conducted using American Public Health Association (APHA) methods to determine physico-chemical parameters; appearance, odour, colour, taste, chloride, pH, sulphate, copper, zinc, iron, nitrate and bacteriological parameters; coliform organism and Escherichia coli $(E$-coli) against the world health organization (WHO) drinking water standard. Water samples were clear and odourless. Most of the parameters tested from both sources; groundwater and rainwater were within the recommended standard. Results from short term water quality parameters taken from 2010-2012 were relatively within the same range while the long-term decadal water quality parameters showed slight variation compared to the short term. Heavy metals showed remarkable variation in 2019 while bacteriological parameters from both water sources were above the permissible threshold. For potable use, water sources require adequate treatment. Boiling or disinfection is recommended until water samples have been retested to ascertain that contamination has been eliminated. In addition, home watertreatment through the use of filters, solar disinfection, or flocculants should be provided to make the water safe.
\end{abstract}

Keywords: Groundwater, Leper settlement, Rainwater quality, Water Standard, Water quality.

\section{INTRODUCTION}

Water is a basic necessity and the heart of Millennium Development Goals (MDGs). All around the world safe water is yearned for by everyone. It is therefore important that adequate supplies of water be developed to preserve and sustain life. Safe water supply is the main concern in development assistance projects for people in developing countries because it is the fundamental and most essential requirement for establishing and maintaining a healthy life. It is also the most effective way to battle water borne diseases such as diarrhea, cholera, typhoid and other forms of communicable and contagious diseases such as leprosy.

Little is known about water quality in most leper colonies despite their susceptibility to diseases and injury. More attention has rather been on the supply and equitable distribution of water to urban and rural populations largely to the neglect of isolated colonies. Several studies on water supply in urban and rural areas but limited reports on safe water supply for secluded areas with vulnerable people living with disability and limited mobility because of fore and limb impairment [1]. Despite all efforts by governments and
Published Online: August 31, 2021

ISSN: $2684-4478$

DOI $: 10.24018 /$ ejchem.2021.2.3.68

\section{R. A. Olaoye *}

Civil Engineering Department, Ladoke Akintola University of Technology, Ogbomoso, Nigeria.

(e-mail: raolaoye@lautech.edu.ng) A. O. Coker Civil Engineering Department, University of Ibadan, Nigeria.

(e-mail: cokerwale@yahoo.com)

M. K. Sridhar

Department of Environment Health, Faculty of Public Health, University of Ibadan, Nigeria.

(e-mail: mkcsridhar@gmail.com) private organizations to bring potable water to poorer people of the world, the situation is still dire for the lepers. The reasons are many and varied but generally speaking, the lepers in most developing countries cannot afford the capital intensive and technically complex water supply systems which are widely promoted by governments and agencies throughout the world [2], [3].

Leprosy is one of the chronic diseases that requires global attention. Lepers all over the world dwell in isolation and are known for poor standard of living. Factors contributing to the spread of leprosy are inadequate water quality, exposure to contaminated water, over-crowdedness and behavioural issues like lack of personal hygiene and environmental sanitation as reflected in poor standard of living. These factors provide a conducive environment for keeping the Lepra bacilli alive in the vicinity of the lepers. Provision of safe water strategically reduces exposure to these risk factors and would further reduce the disease [4]-[7]. Adequate water supply is paramount as it would relieve the lepers of the social and public stigma because a safe water supply could improve their livelihood. In addition, lepers' dwell in isolation, from towns and cities so do not have the privilege to hunt for water 
from available sources and when nearby source(s) dry up, the ability to walk to available sources like streams, rivers, or ponds becomes strenuous due to the impairment in one or both limbs -hands and foot. More so, such sources are prone to pollution from diverse sources, man and animal alike. Sewage and housing management for the lepers [1], [8] are important issues, but this can only be achieved through the provision of an adequate supply of water. This study assessed the quality of water within a Nigerian leper colony over a three short term interval to ten years interval.

Variation of water quality in time and space are caused by either natural or anthropogenic factors (including climate, hydrology/seasonal rainfall variation, geology, groundwater rich in sulphate, water-rock interactions, soil type, land use, land cover, water management, and water use- constant groundwater pumping). Others include sedimentation, runoff, erosion, dissolved oxygen, $\mathrm{pH}$, temperature, decayed organic materials, detergents, oil and grease, agricultural activities pesticides, industrial discharges [9]. On the other hand, rainwater quality variations are often influenced by the quality of roof runoff, roof material, the physical boundary condition of roofs, characteristics of rainfall, type of storage container, first flush operation, acid rain, other meteorological factors, and proximity to pollution sources [10], [11].

\section{MethodOLOGY}

\section{A. Study Location}

The colony lies on longitudes $4014^{\prime} 50^{\prime \prime}$ and $4015^{\prime} 20^{\prime \prime}$ east and latitudes $805^{\prime} 30^{\prime \prime}$ and $806^{\prime} 0^{\prime \prime}$ north of the equator. The landmass of the colony is about $1.2 \mathrm{~km}^{2}$ excluding farmland. The region is covered by grassland and there are two distinct seasons within this leper locality, namely wet and dry seasons. The wet season is the period for rainfall, which is between April and October characterized by continuous rainfall. The dry season spans between November and March and is characterized by hot weather. Between December and early January, the weather is dry and often with a cold breeze that lowers the temperature while the temperature rises from February to March. Mean temperature is between $27-30{ }^{\circ} \mathrm{C}$ while sunshine hours per day range from 2.4 hours in August to 7 hours in February. It has a humid tropical climate; the rainfall pattern is remarkably constant ranging between 1,080 $\mathrm{mm}$ to $1,500 \mathrm{~mm}$ annually. A major part of the rain is received in April-October. Hence, it is characterized by communal farming systems that support only a marginal existence of the lepers.

\section{B. Water Source Assessment}

Groundwater is a major natural resource contributing to the water supply system in this colony but during the rainy season, rain provides valuable quantity for general use. Seven shallow wells and two deep wells were denoted as W1 - W7 and B1-B2, respectively, and two rainwater tanks were identified and analyzed for physicochemical and bacteriological characteristics within the colony. Two (2) corrugated aluminum roofs sloped at $35^{\circ}$ and $45^{\circ}$ were selected for rainwater harvesting. The external drainage from the roofs was modified to bring the water to a central point into the collection tanks. Plastic piping connects the rainwater into each of the tanks. Screens were fitted to cover the tank inlet to prevent the entry of mosquitoes and to catch any large particles that make it past the gutter screening. Early rains were allowed to flush the roof catchment or to "wash" the roof through a first flush mechanism. Once the roof was washed by the rainwater, the rest of the water was allowed into the tank. Samples were taken from the running tap on the tank after 2 minutes to ensure that stagnant water was flushed before collection. At the end of each year, tanks were completely emptied and cleaned before rainwater was harvested in the subsequent year.

\section{Water Sampling, Collection, and Characterization}

Duplicate water samples were collected from each of the water sources (shallow wells, boreholes and rainwater tanks) in sterilized bottles on weekly basis between June and August for each year $(2010,2011,2012$, and 2019) and characterized for physico-chemical parameters; appearance, colour, odour, turbidity, $\mathrm{pH}$, chloride, alkalinity, sulphate, hardness, copper, zinc, iron, silica, nitrate, filterable and non- filterable solids and bacteriological parameters; coliform organism and Escherichia coli (E-coli). Water samples collected were immediately transported to the laboratory for characterization. All reagents and chemicals used were of analytical grade and distilled - deionized water was used in all preparation and analyses. Colour was determined by the colorimetric method. The $\mathrm{pH}$ was measured with a $\mathrm{pH}$ meter. Turbidity was measured using a portable turbidity meter. Laboratory titration and rapid method with kits were used for the estimation of chloride, alkalinity, hardness, sulphate (turbidimetric method), heavy metals (copper, zinc, iron) were determined using atomic absorption spectrophotometer while bacteriological parameters were determined using Most Probable Number (MPN). Tests were carried out as described by American Public Health Association (APHA, 1998) [12] methods for the examination of water and wastewater. The average value of each parameter tested was estimated and recorded against the World Health Organization (WHO) water standard [13].

\section{RESULTS AND DISCUSSION}

\section{A. Water Supply}

The colony is not supplied with pipe-borne water. Groundwater is a major natural resource contributing to the water supply system in this colony but during the rainy season, rain provides valuable quantity for general use. The existing hand-dug wells were excavated with diameters large enough to accommodate one or two men with shovels digging down to the water table. Each has a concrete ring of $3 \mathrm{ft}$ (about $1 \mathrm{~m}$ ) in diameter. The hand-dug wells provided a temporary and low-tech solution to accessing groundwater for the lepers. It has low operational and maintenance costs because water is extracted using manual drawing with a bucket without the need for a pump. However, individual water withdrawal with buckets often poses contamination into the water, for the deep wells, pumps were employed for lifting water to the surface whenever electricity supply was available. Most of the wells were designed, constructed, and donated by charity groups/clubs outside the colony at one time or another for the benefit of the lepers. The alternative source of water for this 
community has been precipitation from rainwater. At every period of rainfall, lepers harness this natural supply of water freely. Individuals harvest this in various degrees in containers, from as little as a liter to as large as a 120 liter plastic storage. Rainwater harvesting played a very significant role in the supply of water in this secluded community.

\section{B. Change in Groundwater Quality}

Average laboratory results for groundwater quality are presented in Table I-IV for 2010, 2011, 2012, and 2019 respectively. The appearance of the groundwater samples was clear with tiny or fluffy particles except for water samples from W1 and W2 which were slightly pale and brown with numerous particles respectively.

The colour of most of the groundwater samples was below the maximum permissible limit of 15 Units except for samples from W3, W6 and W7 which maintained high colour values for the three consecutive years as reflected in Fig. 1a. High colour value could be due to the presence of both floatable and dissolved particles. Colour values of the selected wells were reduced and relatively the same with little variation after a 10 years interval.

Turbidity was adequate with values ranging from $0.02-0.42$ NTU. Turbidity value below 1 NTU is considered adequate for drinking water. The first two years maintained relatively the same turbidity values, an increase in turbidity was observed after a decade as presented in Figure 1b though, within the permissible limits, the decline in groundwater quality had been reported [14]. The $\mathrm{pH}$ concentration expresses the intensity of the acid or alkaline condition of the water. The generally accepted range for $\mathrm{pH}$ in water is 6.5 to 8.5 with an upper limit of 9.5 . The $\mathrm{pH}$ value indicated that most of the samples were of moderate alkalinity with values ranging from 6.8-7.4. The $\mathrm{pH}$ value of the groundwater samples shows gradual reduction in the third year and after a decade except for samples from $\mathrm{W} 2$ and BH1 with the increase in value as presented in Fig. 1c. Alkaline $\mathrm{pH}$ range with negligible variation was also reported in 18 wells [15] in periods of high and low water availability.

There was no rapid fluctuation in chloride level from 20102012 and 2019 as shown in Fig. 1d. Hence, the concentration levels were relatively the same. Chloride values were adequate, all fell below the permissible limit of $250 \mathrm{mg} / \mathrm{L}$. Remarkable spatial variations of chloride had been reported in 29 wells monitored over a decade [16] Chloride may get into groundwater from rocks containing chlorides or from agricultural runoff. Chloride corrodes metals and affects the taste of water. Higher chloride values between $287-308 \mathrm{mg} / \mathrm{L}$ had been reported [15]. Natural groundwater may have chloride concentration of less than $10 \mathrm{mg} / \mathrm{L}$, but when chloride leaches from chemical fertilizers on agricultural discharge onto the land surface the chloride concentration may increase.

Total alkalinity, a measure of the amount of alkaline compounds in the water, such as carbonates, bicarbonates and hydroxides is considered acceptable in the range of 100 to $500 \mathrm{mg} / \mathrm{L}$. Alkalinity values obtained were between 20 to 198 $\mathrm{mg} / \mathrm{L}$ as presented in Fig. 1e. Throughout the period of the test, water samples from all sources had a total alkalinity value below $200 \mathrm{mg} / \mathrm{L}$. Sulphate values were less than 20 $\mathrm{mg} / \mathrm{L}$ for the first two years but between 42 and $54 \mathrm{mg} / \mathrm{L}$ in 2012 and 2019 except for samples from W1 and BH2 which were less than $35 \mathrm{mg} / \mathrm{L}$, indicative of the increase in chemical loading into the water or from soils and rocks containing sulphate minerals. However, the values obtained were within the WHO threshold. Remarkable variation of Sulphate had been reported in groundwater samples [16].

TABLE I: GROUNDWATER QUALITY (2010)

\begin{tabular}{|c|c|c|c|c|c|c|c|c|c|}
\hline \multirow{2}{*}{ Parameters } & \multicolumn{9}{|c|}{ Well identification } \\
\hline & W1 & W2 & W3 & W4 & W5 & W6 & W7 & BH1 & $\mathrm{BH} 2$ \\
\hline Appearance & Clear & Clear & Cloudy & Clear & Clear & Cloudy & Cloudy & Clear & Clear \\
\hline Odour & Odourless & Odourless & Odourless & Odourless & Odourless & Odourless & Odourless & Odourless & Odourless \\
\hline Sulphate & $<20$ & $<20$ & $<20$ & $<20$ & $<20$ & $<20$ & $<20$ & $<20$ & $<20$ \\
\hline Copper & ND & ND & ND & ND & ND & ND & ND & ND & ND \\
\hline Iron & ND & ND & ND & ND & ND & ND & ND & ND & ND \\
\hline Zinc & ND & ND & ND & ND & ND & ND & ND & ND & ND \\
\hline Nitrate & 0.9 & 0.1 & 0.9 & 0.2 & 0.5 & 0.2 & 0.9 & 0.2 & 0.1 \\
\hline Magnesium ion & Present & Present & Present & Present & Present & Present & Present & Present & Present \\
\hline $\begin{array}{c}\text { Coliform } \\
\text { Org.MPN(100ml) }\end{array}$ & Present & Present & Present & Present & Present & Present & Present & Absent & Absent \\
\hline E.Coli $(100 \mathrm{ml})$ & Present & Present & Present & Present & Present & Present & Present & Absent & Absent \\
\hline
\end{tabular}

TABLE II: GROUNDWATER QUALITY (2011)

\begin{tabular}{|c|c|c|c|c|c|c|c|c|c|}
\hline \multirow{2}{*}{ Parameters } & \multicolumn{9}{|c|}{ Well identification } \\
\hline & $\mathrm{W} 1$ & $\mathrm{~W} 2$ & W3 & W4 & W5 & W6 & W7 & BH1 & $\mathrm{BH} 2$ \\
\hline Appearance & Clear & Clear & Cloudy & Clear & Clear & Cloudy & Cloudy & Clear & Clear \\
\hline Odour & Odourless & Odourless & Odourless & Odourless & Odourless & Odourless & Odourless & Odourless & Odourless \\
\hline Sulphate & $<20$ & $<20$ & $<20$ & $<20$ & $<20$ & $<20$ & $<20$ & $<20$ & $<20$ \\
\hline Copper & ND & ND & ND & ND & ND & ND & ND & ND & ND \\
\hline Iron & ND & ND & ND & ND & ND & ND & ND & ND & ND \\
\hline Zinc & ND & ND & ND & ND & ND & ND & ND & ND & ND \\
\hline Nitrate & 0.2 & 0.1 & 0.2 & 0.1 & 0.1 & 0.1 & 0.2 & 0.1 & 0.1 \\
\hline Magnesium ion & Present & Present & Present & Present & Present & Present & Present & Present & present \\
\hline $\begin{array}{c}\text { Coliform } \\
\text { Org.MPN }(100 \mathrm{ml})\end{array}$ & Present & Present & Present & Present & Present & Present & Present & Absent & Absent \\
\hline E.Coli $(100 \mathrm{ml})$ & Present & Present & Present & Present & Present & Present & Present & Absent & Absent \\
\hline
\end{tabular}


TABLE III: GROUNDWATER QUALITY 2012

\begin{tabular}{|c|c|c|c|c|c|c|c|c|c|}
\hline \multirow{2}{*}{ Parameters } & \multicolumn{9}{|c|}{ Well identification } \\
\hline & W1 & W2 & W3 & W4 & W5 & W6 & W7 & BH1 & $\mathrm{BH} 2$ \\
\hline Appearance & $\begin{array}{l}\text { Clear with } \\
\text { TP }\end{array}$ & $\begin{array}{l}\text { Clear with } \\
\text { FP }\end{array}$ & $\begin{array}{l}\text { Clear with } \\
\text { particles }\end{array}$ & $\begin{array}{l}\text { Clear with } \\
\text { FP }\end{array}$ & $\begin{array}{l}\text { Clear with } \\
\text { TP }\end{array}$ & $\begin{array}{l}\text { Clear with } \\
\text { particles }\end{array}$ & $\begin{array}{l}\text { Clear with } \\
\text { particles }\end{array}$ & $\begin{array}{l}\text { Clear with } \\
\text { FP }\end{array}$ & $\begin{array}{c}\text { Clear with } \\
\text { TP }\end{array}$ \\
\hline Odour & Odourless & Odourless & Odourless & Odourless & Odourless & Odourless & Odourless & Odourless & Odourless \\
\hline Sulphate & $<35$ & 54 & 48 & 44 & 40 & 46 & 42 & 42 & $<35$ \\
\hline Calcium hardness & 80 & 120 & 28 & 58 & 54 & 44 & 52 & 76 & 20 \\
\hline Calcium ion & 32 & 48 & 11.2 & 23.2 & 21.6 & 17.6 & 20.8 & 30.4 & 30.4 \\
\hline Magnesium hardness & 42 & 6 & 16 & 12 & 18 & 31 & 14 & 16 & 18 \\
\hline Magnesium ion & 10.5 & 1.5 & 3.9 & 2.9 & 4.4 & 7.75 & 3.5 & 3.9 & 4.4 \\
\hline Copper & 0 & 0 & 0 & 0 & 0 & 0 & 0 & 0 & 0 \\
\hline Iron as $\mathrm{Fe}_{2} \mathrm{O}_{3}$ & 0 & 0 & $<0.25$ & 0 & 0 & 0 & 0 & 0 & $<0.25$ \\
\hline Silica & 6 & $<4$ & $<4$ & 4 & 4 & $<4$ & $<4$ & 6 & $<4$ \\
\hline Zinc & ND & ND & ND & ND & ND & ND & ND & ND & ND \\
\hline Nitrate $\mathrm{NO}_{3}$ & $<4.4$ & $<4.4$ & $<4.4$ & $<4.4$ & $<4.4$ & $<4.4$ & $<4.4$ & $<4.4$ & $<4.4$ \\
\hline Nitrate $-\mathrm{NO}$ & $<1.0$ & $<1.0$ & $<1.0$ & $<1.0$ & $<1.0$ & $<1.0$ & $<1.0$ & $<1.0$ & $<1.0$ \\
\hline Nitrite- $\mathrm{NO}_{3}$ & $<0.02$ & $<0.02$ & $<0.02$ & $<0.02$ & $<0.02$ & $<0.02$ & $<0.02$ & $<0.02$ & $<0.02$ \\
\hline Nitrite- NO & $<0.07$ & $<0.07$ & $<0.07$ & $<0.07$ & $<0.07$ & $<0.07$ & $<0.07$ & $<0.07$ & $<0.07$ \\
\hline Total filterable solids & 62 & 60 & 32 & 74 & 38 & 31 & 109 & 46 & 46 \\
\hline $\begin{array}{l}\text { Total Non- filterable } \\
\text { solids }\end{array}$ & 18 & 22 & 16 & 32 & 20 & 27 & 59 & 26 & 14 \\
\hline $\begin{array}{c}\text { Coliform } \\
\text { Org.MPN(100ml) }\end{array}$ & Present & Present & Present & Present & Present & Present & Present & Absent & Absent \\
\hline E-Coli MPN(100ml) & Present & Present & Present & Present & Present & Present & Present & Absent & Absent \\
\hline \multicolumn{10}{|c|}{ TABLE IV: GROUNDWATER QUALITY 2019} \\
\hline \multirow{2}{*}{ Parameters } & \multicolumn{9}{|c|}{ Well identification } \\
\hline & W1 & $\mathrm{W} 2$ & W3 & W4 & W5 & W6 & W7 & BH1 & $\mathrm{BH} 2$ \\
\hline Appearance & $\begin{array}{l}\text { Clear with } \\
\text { TP }\end{array}$ & $\begin{array}{l}\text { Clear with } \\
\text { FP }\end{array}$ & $\begin{array}{l}\text { Clear with } \\
\text { particles }\end{array}$ & $\begin{array}{l}\text { Clear with } \\
\text { FP }\end{array}$ & $\begin{array}{c}\text { Clear with } \\
\text { TP }\end{array}$ & $\begin{array}{l}\text { Clear with } \\
\text { particles }\end{array}$ & $\begin{array}{l}\text { Clear with } \\
\text { particles }\end{array}$ & $\begin{array}{l}\text { Clear with } \\
\text { FP }\end{array}$ & $\begin{array}{c}\text { Clear with } \\
\text { TP }\end{array}$ \\
\hline Odour & Odourless & Odourless & Odourless & Odourless & Odourless & Odourless & Odourless & Odourless & Odourless \\
\hline Sulphate & $<35$ & $<35$ & $<35$ & $<35$ & $<35$ & $<35$ & $<35$ & $<35$ & $<35$ \\
\hline Calcium hardness & 40 & 38 & 28 & 48 & 33 & 28 & 37 & 79 & 49 \\
\hline Calcium ion & 16 & 15.2 & 11.2 & 19.2 & 13.23 & 11.2 & 14.8 & 31.55 & 19.6 \\
\hline Copper & 0.002 & 0.001 & 0.001 & 0.001 & 0.001 & 0.001 & 0.001 & 0.01 & 0.001 \\
\hline Iron as $\mathrm{Fe}_{2} \mathrm{O}_{3}$ & 0.4 & 0.4 & 0.53 & 0.5 & 0.45 & 0.4 & 0.4 & $<0.3$ & $<0.3$ \\
\hline Silica & 1.0 & 1.0 & 1.0 & 1.0 & 1.0 & 1.0 & 1.0 & 1.1 & 1.0 \\
\hline Zinc & $<1.0$ & $<1.0$ & $<1.0$ & $<1.0$ & $<1.0$ & $<1.0$ & $<1.0$ & $<1.0$ & $<1.0$ \\
\hline Nitrate $\mathrm{NO}_{3}$ & $<1.0$ & $<1.0$ & $<1.0$ & $<1.0$ & $<1.0$ & $<1.0$ & $<1.0$ & $<1.0$ & $<1.0$ \\
\hline Nitrate $-\mathrm{NO}$ & $<1.0$ & $<1.0$ & $<1.0$ & $<1.0$ & $<1.0$ & $<1.0$ & $<1.0$ & $<1.0$ & $<1.0$ \\
\hline Nitrite- $\mathrm{NO}_{3}$ & $<0.02$ & $<0.02$ & $<0.02$ & $<0.02$ & $<0.02$ & $<0.02$ & $<0.02$ & $<0.02$ & $<0.02$ \\
\hline Nitrite- NO & $<0.07$ & $<0.07$ & $<0.07$ & $<0.07$ & $<0.07$ & $<0.07$ & $<0.07$ & $<0.07$ & $<0.07$ \\
\hline Total solids & 150 & 132 & 148 & 136 & 138 & 138 & 138 & 125 & 129 \\
\hline Total filterable solids & 0.1 & 0.08 & 0.092 & 0.08 & 0.09 & 0.09 & 0.12 & 0.014 & 0.09 \\
\hline $\begin{array}{l}\text { Total Non- filterable } \\
\text { solids }\end{array}$ & 149.9 & 131.9 & 147.91 & 135.92 & 137.9 & 137.91 & 137.88 & 124.99 & 128.9 \\
\hline $\begin{array}{c}\text { Coliform Org. MPN / } \\
100 \mathrm{ml}\end{array}$ & $120+$ & $180+$ & $180+$ & $180+$ & $180+$ & $180+$ & $180+$ & 50 & 35 \\
\hline E-Coli $\mathrm{MPN}(100 \mathrm{ml})$ & Present & Present & Present & Present & Present & Present & Present & Absent & Absent \\
\hline
\end{tabular}

Counts of Escherichia Coli (E. coli)

FP = Fluffy particles; TP = Tiny particles; NTU (Nephelo-metric Turbidity Units); .ND = Not detected

Note: All units in $\mathrm{mg} / \mathrm{L}$ except $\mathrm{pH}$ and otherwise stated.

Total hardness values obtained were relatively the same for all the groundwater samples from 2010-2012. Slight variation in value was observed in 2019 as presented in Fig. 1f. Samples were between soft to moderately hard. Hardness values were below $150 \mathrm{mg} / \mathrm{L}$.

Copper and Zinc as trace elements were below detection level in all the water samples between 2010-2012, similar results were reported [15]. This shows low intrusion of industrial wastes or corrosion of copper pipes or galvanized pipes (Zinc), especially within the deep wells. However, traces of both metals were detected after a decade. Previous work carried out in an Algerian aquifer revealed traces of detectable zinc ion concentration during high water supply even though low periods presented no-detectable level [15]. Copper ions are often due to long-term corrosion of pipes which should be monitored as the excessive concentration of copper in drinking water causes vomiting, diarrhea, stomach cramps, nausea, liver and kidney disease. Zinc in groundwater is often due to erosion of minerals from rocks and soils or the leaching of zinc-rich fertilizers into the water or pipes coated with zinc.

Iron was below the detection limit from all the water samples analyzed from all the wells in 2010 and 2011. In 2012 iron was detected from water samples taken from W3 and $\mathrm{BH} 2$ with concentration $<0.24 \mathrm{mg} / \mathrm{L}$ and after a decade the concentration of iron in the shallow and deep wells was between $0.25-0.53 \mathrm{mg} / \mathrm{L}$, a similar observation was reported in several wells [15]. All the shallow wells had the iron concentration of more than $0.3 \mathrm{mg} / \mathrm{L}$ while the two deep wells had iron levels less than $0.3 \mathrm{mg} / \mathrm{L}$ in 2019 . Iron levels as low as 0.2 to $0.3 \mathrm{mg} / \mathrm{L}$ will usually cause the staining of laundry articles, cooking and eating utensils, and plumbing fixtures. 
Iron occurs naturally in the aquifer and can be increased by the dissolution of ferrous borehole and hand-pump components. WHO and EPA recommend the iron level of $0.3 \mathrm{mg} / \mathrm{L}$ to prevent staining of fixtures and fittings. Excessive iron in water often results in metallic taste and offensive odour and causes nausea, vomiting and stomach pain.

Low nitrate and nitrite values were obtained in 2010 and 2011 with concentrations $<1$ and $<0.07 \mathrm{mg} / \mathrm{L}$, respectively. The concentration of nitrate increased in 2012 to $<4.4 \mathrm{mg} / \mathrm{L}$ and decreased to $<1 \mathrm{mg} / \mathrm{L}$ after a decade (2019). Nitrate and nitrite concentrations were within the permissible limit. Values were less than $4.4 \mathrm{mg} / \mathrm{l}$. Higher nitrate concentration, but lower nitrite value had been reported [15], [16] Nitrate concentration in the water samples is an indication of contamination by livestock waste or excessive fertilizer or leachate from the dumpsite.

Bacteriological tests indicated that water samples from deep wells (BH1 and $\mathrm{BH} 2)$ were of relatively good quality with non-detectable coliform organisms and E-Coli per $100 \mathrm{ml}$. The Presence of coliform bacterial and E-coli contamination in shallow wells indicates the intrusion of human waste, animal waste deposit or intrusion of subsurface water since

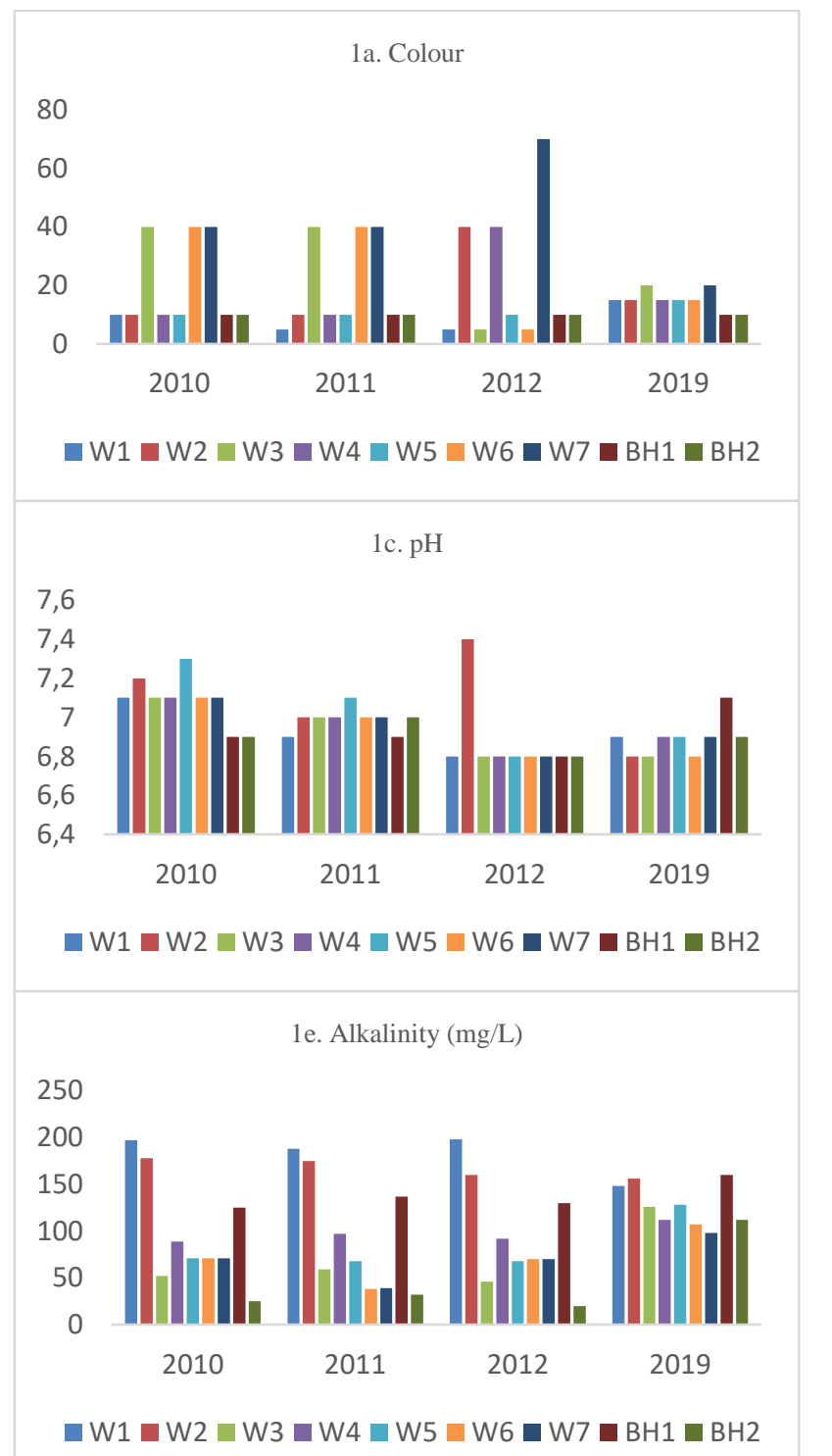

most of the wells were shallow, water extraction with the use of pulling buckets are also probable means of water pollution and contamination into these wells as most of the well had damaged lids. Similar bacteriological results had been reported for groundwater around the vicinity of the colony [17]. Similarly, a study on physicochemical and bacteriological quality of groundwater (shallow and deep wells) confirmed that physicochemical parameters of groundwater tested were within the permissible limits while bacteriological concentration (total and faecal coliforms) often makes the water not potable [18], [19]. Groundwater is the primary source of drinking water worldwide and is often cited as a high-quality source that requires less treatment than surface water. Bacteriological concentration in groundwater often requires great concern because water quality standards specify that water samples tested should be free from excessive metal ion concentration and bacteriological contamination and it should be potable and palatable for drinking. Repair and well modification are required for all the shallow wells. For potable use, the water requires disinfection through chlorination, filtration, ultraviolet irradiation or ozonation.

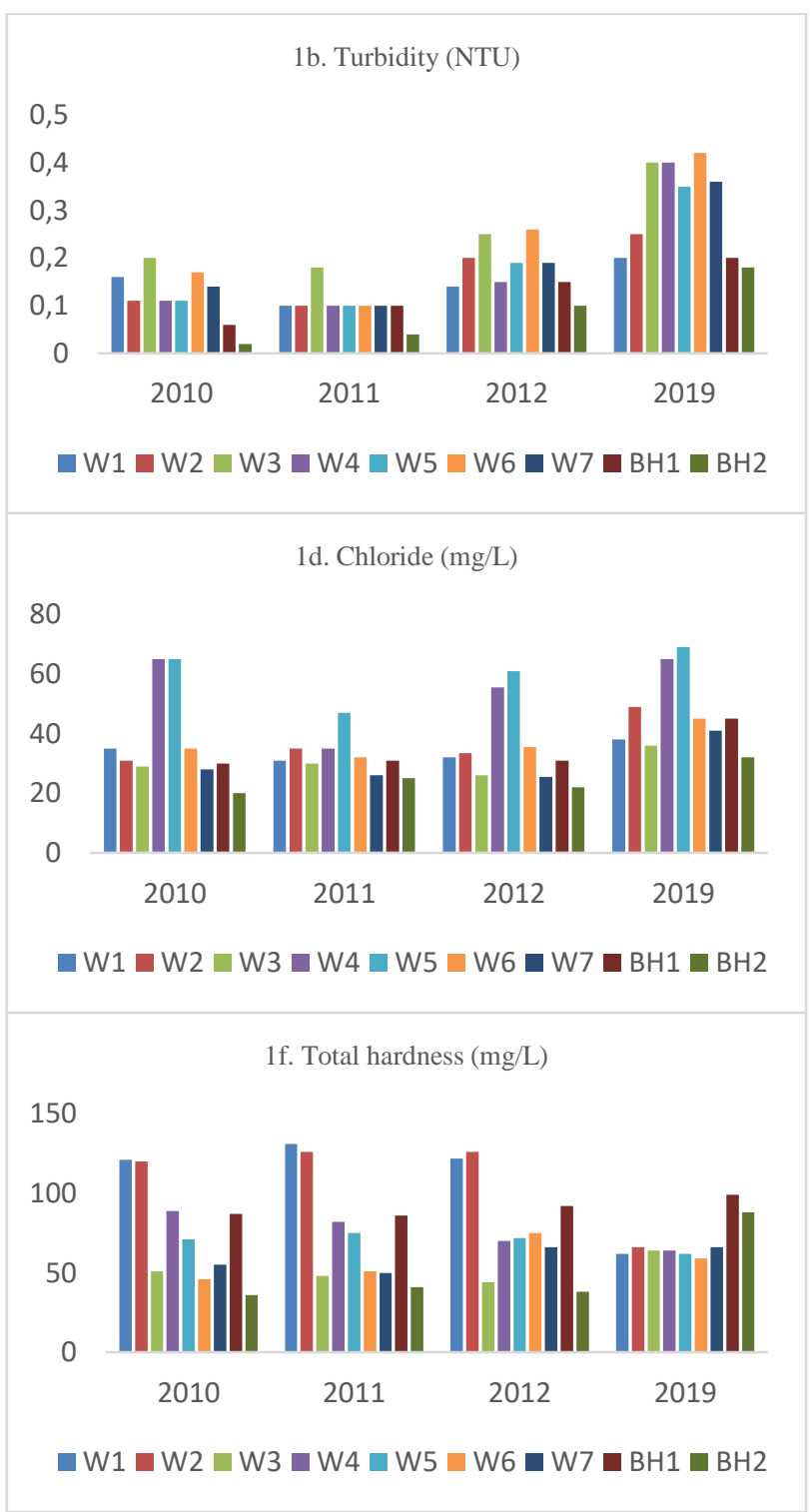

Fig. 1 (a)-(f): Variation of Other Physico-chemical Parameters of Groundwater Samples. 


\section{Change in Rainwater Quality}

Rainwater from properly maintained roof catchments, gutters, and storage tanks is generally safe to drink with little treatment. However, reports of disease outbreaks linked with drinking rainwater are often common due to several components of the rainwater harvesting system that require care and attention. The roof material does not only determine the run-off coefficient, it also influences the water quality of the harvested rainwater. Table $\mathrm{V}$ shows the average laboratory results obtained from rainwater samples taken from the rainwater tanks. Colour, taste, and odour were unobjectionable.

The average turbidity of the rainwater samples was excellent, with values ranging between 0.21-2.22 NTU. Little variation exited between $2010-2012$ but wide variation was observed after a decade (2019), though less than the permissible. The average $\mathrm{pH}$ value of the water sample ranged from $6.65-6.8$ at $25^{\circ} \mathrm{C}$ indicating that the samples are moderately acidic, this is lesser than that from the groundwater which ranged from 6.8-7.4. Average chloride concentration lies between 170-194 $\mathrm{mg} / \mathrm{L}$ which is permissible. Alkalinity values were below $26 \mathrm{mg} / \mathrm{L}$ for all the samples collected from 2010-2012, a higher value was observed in 2019. Sulphate concentrations were less than 20 ppm below the permissible value of 250 . Total hardness values were between $20-45 \mathrm{mg} / \mathrm{L}$. Copper was below the detectable level throughout the period of testing. Iron and zinc were below detectable levels in the rainwater samples indicating the absence of the intrusion of trace metals from 2010-2012. Traces of both metals was observed after a decade, the similar value was reported [20], [21]. Nitrate was present in the sample's indicative of the probability of the intrusion of decaying organic matter, although the concentrations were within the permissible. The maximum acceptable concentration in drinking water is $10 \mathrm{mg} / \mathrm{L}$. Another parameter of greater concern is the bacteriological contamination; the average value was more than one in all the samples tested. The presence of bacteriological indicators such as Escherichia coli (E. coli) provides positive proof of the faecal origin of such pollution.

TABLE V: RAINWATER QUALITY

\begin{tabular}{|c|c|c|c|c|c|}
\hline Parameters & 2010 & 2011 & 2012 & 2019 & WHO Standard \\
\hline & Mean + SD & Mean + SD & Mean + SD & Mean + SD & \\
\hline Colour & Colourless & Colourless & Colourless & 15 & $15 \mathrm{TCU}$ \\
\hline Odour & unobjectionable & unobjectionable & unobjectionable & unobjectionable & Odourless \\
\hline Turbidity & $0.21 \pm 0.01$ & $0.28 \pm 0.005$ & $0.24 \pm 0.0057$ & $2.22 \pm 0.01$ & 5 \\
\hline $\mathrm{pH}$ value at $25^{\circ} \mathrm{C}$ & $6.8 \pm 0.07$ & $6.65 \pm 0.07$ & $6.7 \pm 0.035$ & $6.8 \pm 0.05$ & $6.5-8.5$ \\
\hline Chloride & $180 \pm 0.35$ & $170 \pm 0.70$ & $191 \pm 1.76$ & $194 \pm 0.91$ & 250 \\
\hline Total alkalinity & $24 \pm 0.21$ & $26 \pm 0.56$ & $17 \pm 0.28$ & $35 \pm 1.4$ & $50-100$ \\
\hline Sulphate & $<20$ & $<20$ & $<20$ & $<20$ & $100-250$ \\
\hline Total Hardness & $20 \pm 0.63$ & $28 \pm 0.56$ & $38 \pm 0.56$ & $45 \pm 0.35$ & $100-300$ \\
\hline Calcium hardness & $12 \pm 0.42$ & $19 \pm 0.91$ & $25 \pm 0.49$ & $37 \pm 0.77$ & \\
\hline Magnesium hardness & $8 \pm 0.42$ & $9 \pm 0.45$ & $13 \pm 0.21$ & $8 \pm 0.08$ & \\
\hline Copper & ND & ND & ND & ND & 2 \\
\hline Iron & ND & ND & ND & $0.23 \pm 0.007$ & 0.3 \\
\hline Zinc & ND & ND & ND & $0.003 \pm 0.0003$ & 5 \\
\hline Nitrate & $4.21 \pm 0.04$ & $4.18 \pm 0.08$ & $4.17 \pm 0.014$ & $4.23 \pm 0.07$ & 10 \\
\hline Magnesium ion & Present & Present & Present & Present & 20 \\
\hline Coliform org./100ml & $30 \pm 0.28$ & $32 \pm 0.7$ & $35 \pm 1.0$ & $50 \pm 3.5$ & Not detectable \\
\hline E-coli $\mathrm{MPN}(100 m l)$ & Present & Present & Present & Present & $\begin{array}{l}\text { Not detectable in any } 100 \mathrm{ml} / \\
\text { sample }\end{array}$ \\
\hline
\end{tabular}

$\mathrm{SD}=$ Standard deviation. All units in $\mathrm{mg} / \mathrm{L}$ except $\mathrm{pH}$ and otherwise stated.

\section{CONCLUSION AND RECOMMENDATIONS}

Most of the physico-chemical parameters of the groundwater and rainwater samples analyzed showed little variation between the decadal years and were within the permissible limits. The temporal slight variation in groundwater quality was controlled by the dilution of rainwater per time. Copper was below the detectable level from both sources from 2010-2012 but detected in 2019; iron and zinc were below detectable level in groundwater and rainwater samples from 2010-2012, but detectable after a decade in both sources in 2019. All the shallow wells had iron concentrations of more than $0.3 \mathrm{mg} / \mathrm{L}$ while the two deep wells had iron levels of less than $0.3 \mathrm{mg} / \mathrm{L}$ in 2019 . Bacteriological parameters were not within the permissible standard from both sources except from the two deep wells. Repair and well modification is required for all the shallow wells. For potable use, water sources require adequate treatment. Boiling or disinfection is recommended until water samples have been retested to ascertain that contamination has been eliminated. Groundwater from underground aquifers should be properly channeled using appropriate techniques and a rainwater harvesting system should be adequately maintained to ensure adequate and sustainable water quality. Home water treatment through the use of filters, solar disinfection, or flocculants, should be provided to make both water sources safe.

\section{ACKNOWLEDGEMENT}

The authors appreciate the constant support of the staff and management of the leper colony. All who assisted in the study are also appreciated.

\section{REFERENCES}

[1] Coker A. O., Oluremi J. R., Adeshiyan R. A., Sridhar M. K., Coker M. E., Booth C.A, Millington J. A, and Khatib J. M. Wastewater Management in a Nigerian Leper Colony", Journal of Environmental Engineering and Landscape Management, 2011, 19 (3):260-269.

[2] Olaoye, R. A., Coker, A. O. and Sridhar, M. K. Securing Domestic Water Supply in Nigerian Leper Colony, International Journal of Engineering - Under Uncertainty Hazards Assessment and Mitigation (IJEUUHAM), 2013a, 5 (1): 28-37 
[3] Olaoye, R.A., Coker, A.O., Sridhar, M.K. and Adewole, E.M. Examining the Effectiveness of Rainwater Collection Systems in a Nigerian Leper Colony Using the Behavioural Model, ARPN Journal of Engineering and Applied Sciences, 2013b, 8 (1): 1-8.

[4] Jariwala D.A, Patel B.H, Godara N.R, and Kantharia S.L. SocioDemographic and Environmental Correlates of Leprosy: A hospital based cases control study, National Journal of Community Medicine, 2013, 4(3): 369-376.

[5] Enwereji E.E, Ahuizi E.R, Iheanocho O.C and Enwereji K.O. Medical Rehabilitation of leprosy patients discharged home in Abia and Ebonyi States of Nigeria, Oman Medical Journal, 2011, 26(6):393-398.

[6] Kerr-Pontes L.R.S, Montenegro A.C.D, Barreto M.L, Werneck G.L and Feldmeier H. Inequality and leprosy in Northeast Brazil; an ecological study, International Journal of Epidemiology, 2004, 33(.2): 262-269.

[7] White C. Socio-cultural considerations in the treatment of leprosy in Rio de Janeiro, Brazil, Lepr Rev., 2002, 73: 356-365.

[8] Coker, A. O., Adeshiyan, R. A., Oluremi, J. R., Sridhar, M. K., Coker, M. E., Booth, C. A. and Khatib, J. M. Challenges of Waste Management in a Nigerian Leper Colony, International Journal of Environmental Studies, 2008, 65(2):183-195.

[9] Ha, K.; Lee, E.; An, H.; Kim, S.; Park, C.; Kim, G.-B.; Ko, K.-S. Evaluation of Seasonal Groundwater Quality Changes Associated with Groundwater Pumping and Level Fluctuations in an Agricultural Area, Korea. Water, 2021, Vol. 13, Issue 51. https://doi.org/w13010051.

[10] Olaoye R.A and Olaniyan O.S. Quality of Rainwater from Different Roof Material, International Journal of Engineering and Technology, 2012, 2 (8): 1413-1421.

[11] Zdeb .M., Zamorska J., Papciak D. and Słyś D. The Quality of Rainwater Collected from Roofs and the Possibility of Its Economic Use, Resources, 2020. 9(2), 12.

https://doi.org/10.3390/resources9020012. This article belongs to the Special Issue Water Resources and Climate Change.

[12] APHA. Standard Methods for the Examination of Water and Wastewater, 20 ed. Washington, D.C: American Public Health Ass. WPCF and AWWA, 1998.

[13] WHO. Guidelines for Drinking Water Quality, Vo1.3, Surveillance and Control of Community Application. World Health Organization, Geneva, Switzerland, 2010.

[14] Alexander A.C., Ndambuki J, Salim R. and Manda A. Assessment of Spatial Variation of Groundwater Quality in a Mining Basin, Sustainability, 2017, 9, 823; doi:10.3390/su9050823.

[15] Benhamiche N., Sahi L, Tahar S, Bir H., Madani K. \& Laignel B. Spatial and temporal variability of groundwater quality of an Algerian aquifer: the case of Soummam Wadi, Hydrological Sciences Journal, 2016, 61 (4):775-792. DOI:10.1080/02626667.2014.966723.

[16] Niu B, Wang H., Loáiciga H.A, Hong S., and Shao W. Temporal variations of groundwater quality in the Western Jianghan Plain, China, Science Total Environment, 2017, 1(578): 542-550. doi: 10.1016/j.scitotenv.2016.10.225.

[17] Adetunde, L.A, Glover, R.L.K and Oguntola, G.O. Assessment of the groundwater quality in Ogbomoso Township of Oyo State, Nigeria, IJRRAS, 2011, 18(1): 115-122.

[18] Sabo A. and Christopher E.O. Physicochemical and bacteriological quality of groundwater at Abubakar Tatari Ali Polytechnic Bauchi, Nigeria, European Scientific Journal, 2014, 10(18): 466-478.

[19] Apau A., Acheampong A. and Bepule V. Physicochemical and Microbial parameters of water from hand - dug wells from Nyamebekyere, A surburb of Obuasi, Ghana, International Journal of Science and Technology, 2014, 3(6): 347-351.

[20] Sharma .P and Rai .V. Assessment of rainwater chemistry in the Lucknow metropolitan city, Applied Water Science, 2018, 8:67. Doi.org/10.1007/s13201-018-0705-y.

[21] Chubaka C.E, Whiley H, Edward J.W and Ross K.E. Lead, zinc, copper and cadmium content of water from South Australian Rainwater tanks, International Journal of Environmental Research and Public Health, 2018, 15, 1551. Doi:10.3390/ijerph15071551. 